\title{
A Novel Missense Mutation in the Amino-terminal Domain of the Human Androgen Receptor Gene in a Family with Partial Androgen Insensitivity Syndrome Causes Reduced Efficiency of Protein Translation
}

\author{
Catherine S. Choong, ${ }^{\star \ddagger}$ Charmian A. Quigley, ${ }^{\star \ddagger}$ Frank S. French, ${ }^{\star \ddagger}$ and Elizabeth M. Wilson ${ }^{\star \ddagger}$ \\ $*$ Laboratories for Reproductive Biology and the Departments of ${ }^{\ddagger}$ Pediatrics, and ${ }^{\S}$ Biochemistry and Biophysics, University of North \\ Carolina, Chapel Hill, North Carolina 27599
}

\begin{abstract}
The role of the androgen receptor (AR) in male sexual differentiation is revealed in part by the analysis of naturally occurring mutations in families with androgen insensitivity syndrome (AIS). We have investigated a family with partial AIS affecting three generations and have identified a $\mathrm{G}$ to $\mathrm{A}$ substitution in the $A R$ gene at the fourth position $3^{\prime}$ from the $A$ of the ATG initiation codon changing the second amino acid residue from glutamic acid to lysine (EK2). Transient expression of the mutant EK2-pCMVhAR expression vector in COS cells revealed decreased translation with a $20-50 \%$ reduction in mutant protein relative to wild type AR by immunoblot analysis. The rate of dissociation of $\left[{ }^{3} \mathrm{H}\right]$ methyltrienolone from the EK2 mutant (half-time $\left[t_{1 / 2}\right]=$ $1.7 \pm 0.08 \mathrm{SE} h$ ) was increased compared with wild type AR $\left(t_{1 / 2}=2.4 \pm 0.11 \mathrm{~h}\right)$. Cotransfection studies using an androgen responsive luciferase reporter vector demonstrated a $50 \%$ reduction in transcriptional activation by EK2. These functional alterations are consistent with the partial AIS phenotype in affected males, corroborate the AR amino-terminal domain effect on kinetics of androgen binding, and provide physiological evidence for earlier translation experiments identifying the nucleotide sequence for optimal translation initiation. (J. Clin. Invest. 1996. 98:1423-1431.) Key words: androgen receptor $\cdot$ mutation $\cdot$ protein translation
\end{abstract}

\section{Introduction}

The androgen receptor $(\mathrm{AR})^{1}$ is a member of the steroid hormone receptor superfamily of ligand dependent transcription factors. AR interacts with specific DNA sequences known as androgen response elements which occur adjacent to and

This work was presented in part at the 77th Annual Meeting of the Endocrine Society, Washington, DC. 1995 (Abstr. P1-513).

Address correspondence to Catherine S. Choong, M.D., Laboratory for Reproductive Biology, University of North Carolina, CB 7500 Room 370 Medical Sciences Research Building, Chapel Hill, NC 27599-7500. Phone: 919-966-5159; FAX: 919-966-2203. E-mail: csy cjrd@med.unc.edu. Charmian A. Quigley's present address is: Charmian A. Quigley, Department of Pediatrics, Section of Pediatric Endocrinology and Diabetes, James Whitcomb Riley Hospital for Children, 702 Barnhill Drive, Room 5984, Indianapolis, IN 46202-5225.

Received for publication 28 March 1996 and accepted in revised form 12 July 1996.

J. Clin. Invest.

(C) The American Society for Clinical Investigation, Inc.

0021-9738/96/09/1423/09 \$2.00

Volume 98, Number 6, September 1996, 1423-1431 within responsive genes, resulting in hormone regulated transcription (1). The receptor shares sequence similarity with other steroid receptors within its three primary functional regions: the amino-terminal, DNA binding, and steroid binding domains. The amino-terminal domain, which constitutes $60 \%$ of the AR coding sequence, is the least conserved and least well defined of the three major domains and contains two polymorphic sequences of glutamine and glycine repeats (2-5). Analyses of AR deletion mutant constructs indicate that the amino-terminal domain is essential for transactivation and is inhibited by the steroid binding domain in the absence of androgen. Recent evidence shows also that the extreme amino terminus is important for receptor stabilization and steroid binding (6). The DNA binding domain is the most highly conserved region and interacts with androgen response elements $(1,2,7)$. The carboxyl-terminal region contains the steroid binding domain, which inhibits transcriptional activation in the absence of androgen, and binds androgen with high affinity resulting in AR activation $(7,8)$.

In our investigation of the molecular basis for androgen resistance in a family with partial AIS, grade III (9), we have identified a $\mathrm{G}$ to $\mathrm{A}$ mutation that results in a glutamic acid to lysine substitution at the second codon in exon 1 of the $A R$ gene. This mutation is situated four nucleotides $3^{\prime}$ of the $\mathrm{A}$ in the ATG initiation codon. In vitro translation experiments have shown previously that a $\mathrm{G}$ in this position relative to the ATG initiation codon affects the initiation of protein synthesis (10). Here we report a novel mechanism of androgen resistance, namely reduced AR protein expression resulting from disruption of the nucleotide initiation sequence for protein translation. Our investigations provide in vivo evidence supporting the importance of the highly conserved sequence alignment at this locus in the optimal initiation of protein translation (10).

\section{Methods}

Studies were carried out with the informed consent of the subjects and the approval of the University of North Carolina at Chapel Hill Institutional Review Board in accordance with the principles expressed in the declaration of Helsinki (World Health Organization, Hong Kong 1990). The family was initially referred for determination of carrier status for androgen insensitivity syndrome (AIS). The pedi-

1. Abbreviations used in this paper: AIS, androgen insensitivity syndrome; AR, androgen receptor; DGGE, denaturing gradient gel electrophoresis; DHT, $5 \alpha$-dihydrotestosterone; DMEM-H, Dulbecco's Modified Eagle's Medium; EMEM, Eagle's minimal essential medium; EK2, androgen receptor mutant expression vector, glutamic acid to lysine at amino acid 2; R1881, $17 \alpha$-methyltrienolone; MMTVluciferase, luciferase reporter vector containing the mouse mammary tumor virus promoter. 
gree is shown in Fig. 1. The index case II-1 (karyotype $46 \mathrm{XY}$ ) was assigned a female sex at birth. At $3 \mathrm{yr}$ of age sex assignment was altered to male. Ambiguous genitalia were characterized by perineal hypospadias, microphallus and labioscrotal fusion, and a urogenital sinus. Testes were present bilaterally in the inguinal canals. Two younger male siblings, subjects II-4 and II-10, had similar phenotypes. A cystourethrogram and vaginogram performed at $9 \mathrm{yr}$ of age in subject II-10 demonstrated a short straight urethra extending into the bladder, absent verumontanum, and a second opening posterior to the urethral meatus leading into a rudimentary vagina. Histology of testicular biopsies from subject II-10 showed narrow seminiferous tubules lined by undifferentiated Sertoli cells and scanty germinal cells. On physical examination at $20 \mathrm{yr}$ of age, subject II-10 was $183-\mathrm{cm}$ tall with a female body habitus, a broad pelvis, gynecomastia, Tanner stage 4 pubic hair development, and absent facial hair. Genitals consisted of inguinal testes, perineoscrotal hypospadias at the apex of marked labioscrotal folds, and a phallus with a stretched length of $2 \mathrm{~cm}(<5$ percentile). The phenotype is consistent with partial AIS, grade III (9). Serum testosterone was $51 \mathrm{nmol} /$ liter (normal male $=10-35 \mathrm{nmol} /$ liter) and estradiol was $199 \mathrm{pmol} /$ liter (normal male $<180 \mathrm{pmol} /$ liter). Gonadotropin levels (LH 2 U/liter and FSH 1 U/liter) were within the laboratory reference range for adult males. A normal sevenfold rise in LH levels was observed following stimulation with $100 \mathrm{U}$ of LHRH. Analysis of $0.2 \mathrm{ml}$ sample of semen revealed azoospermia. Subject II-10 had prominent breast development which required reduction mastectomies at $20 \mathrm{yr}$ of age. Family members did not consent to genital skin biopsy for analysis of fibroblast AR binding characteristics.

AR gene analysis. Genomic DNA was obtained from peripheral blood leukocytes by organic solvent extraction (11). The eight exons of the $A R$ gene were amplified by PCR and exons $2-8$ were screened for single base mutations by denaturing gradient gel electrophoresis (DGGE). All exons were subsequently subjected to direct sequence analysis using methods described in detail elsewhere $(12,13)$. The nucleotide mutation identified was confirmed in two separate sequencing reactions from two primary amplifications of genomic DNA from subject II- 1 and by direct sequencing of DNA from subjects II-4 and II-10.

An allele specific PCR based protocol was developed to identify carriers of the mutation as the glutamine polymorphic repeat was not informative in this family. A mutagenic primer 5'-GAAGTAGGTGGAAGATTCAGCCAAGCTCAATCATG-3', contains a 2 base substitution in its sequence (underlined) creating a $\mathrm{BspH} 1$ restriction site when the EK2 mutation is present. After a 30 cycle PCR amplification of $100 \mathrm{ng}$ genomic DNA using the above primer and the antisense primer 5'-CAGCAGCAGCAAACTGGCGCCGGGA-3', the 202-bp PCR product was digested with BspH1 (New England Biolabs, Beverly, MA). A 171-bp fragment results when the mutant allele is present; no digestion occurs when the normal allele is amplified (see Fig. 3).

Construction of the hAR EK2 mutant cDNA expression plasmid by site directed mutagenesis. The expression plasmid pCMVhAR containing the hAR cDNA (4) was used to construct a mutant AR cDNA containing the AR gene mutation identified in this family. Sequence of the oligonucleotide primer 5'-CTAGCAGGGCAGACTTTCTAGACCGTGTGTCTTC-3' which contains Xba1 and Bgl2 sites, is located 215 nucleotides $5^{\prime}$ of the ATG initiator codon and the antisense primer noted above which contains an Nar1 site were used in PCR amplification of a 399-bp fragment of genomic DNA from subject II-1. The PCR product and wild type expression vector were digested with Nar1 and Bgl2 (GIBCO BRL, Gaithersburg, MD), purified by extraction from $0.5 \%$ agarose, and ligated at room temperature using T4 ligase (Promega Biotech, Madison, WI). Recombinant plasmid obtained from transformed $\mathrm{DH} 5 \alpha^{\mathrm{TM}}$ competent cells was sequenced to confirm the presence of the mutation and the absence of other base changes. The recombinant plasmid pCMVhAR-EK2, designated EK2, contained an additional Xba1 site adjacent to the Bgl2 site enabling differentiation of the mutant EK2 clone from pCMVhAR.
Transient cotransfection assays of transcriptional activity. CV-1 cells (American Type Tissue Culture Collection; Rockville, MD) were plated in $60 \mathrm{~mm}$ dishes at a density of $4.5 \times 10^{5}$ and cultured in Dulbecco's modified essential medium with high glucose (DMEM-H; JRH Biosciences, Lenexa, KS) and 10\% FCS (Irvine Scientific). After $20 \mathrm{~h}$, the cells were transfected with either 10 or $100 \mathrm{ng}$ of pCMVhAR or mutant expression vector and $5 \mu \mathrm{g}$ of the mouse mammary tumor virus promoter (MMTV luciferase) reporter vector (provided by R.M. Evans, Salk Institute, La Jolla, CA) using the calcium phosphate precipitation method (14). $4 \mathrm{~h}$ after transfection the cells were exposed to $15 \%$ glycerol for $4 \mathrm{~min}$ at room temperature and washed twice with Tris buffer (50 mM Tris, pH 7.4, $0.28 \mathrm{M} \mathrm{NaCl}, 6 \mathrm{mM} \mathrm{KCl}, 2$ $\left.\mathrm{mM} \mathrm{CaCl}_{2}, 1 \mathrm{mM} \mathrm{MgCl}, 1.8 \mathrm{mM} \mathrm{NaH} \mathrm{PO}_{4}\right)$. After glycerol shock, and again $20 \mathrm{~h}$ later, the medium was changed to serum-free, phenolred free DMEM-H with $5 \alpha$-dihydrotestosterone (Sigma Chemical Co., St. Louis, MO) at the concentrations indicated in Fig. $6.48 \mathrm{~h}$ after transfection, cells were collected in $0.4 \mathrm{ml}$ lysis buffer (Ligand Pharmaceuticals). Luciferase activity was determined by analysis of relative light units using a Monolight 2010 Analytical Luminescence Laboratory luminometer. All experiments were performed in triplicate.

Assessment of $A R$ expression and androgen binding kinetics. For immunoblot analysis of AR protein, COS-1 cells (ATCC) were transfected in duplicate with the indicated concentrations of AR expression vector (see Fig. 7) using the calcium phosphate precipitation method as described for CV1 cells. The plating density was $4.5 \times 10^{5}$ cells per $60 \mathrm{~mm}$ dish. After glycerol shock, cells were incubated in DMEM-H with $10 \%$ FCS for $48 \mathrm{~h}$ and harvested in $100 \mu \mathrm{l}$ of $2 \% \mathrm{Na}$ dodecyl sulfate (SDS), $10 \%$ glycerol, and $10 \mathrm{mM}$ Tris, $\mathrm{pH}$ 6.8. Immunoblot analysis of COS cell extracts for expressed AR was performed using the polyclonal antibody AR 52 raised against an AR synthetic peptide (amino acids 544-558) (15). Whole cell androgen binding and intracellular androgen dissociation rates were determined in COS cells transiently transfected with the mutant EK2 and wild type pCMVhAR cDNA using DEAE dextran (6). The unlabeled and tritiated synthetic androgen $\left[{ }^{3} \mathrm{H}\right]$ methyltrienolone $\left(\left[17 \alpha\right.\right.$-methyl $\left.-{ }^{3} \mathrm{H}\right] \mathrm{R} 1881 ; 80$ $\mathrm{Ci} / \mathrm{mmol}$; DuPont New England Nuclear, Wilmington, DE) were used in the assays. Protein content was determined by the method of Lowry (16).

Analysis of AR translation efficiency and protein degradation rates. COS cells were plated at a density of $1.2 \times 10^{6}$ cells $/ 10 \mathrm{~cm}$ dish and transfected with $10 \mu \mathrm{g}$ AR expression vector DNA using DEAE dextran. $24 \mathrm{~h}$ after transfection, DMEM-H containing 10\% FCS was replaced with serum free, phenol red-free medium. After a further $24 \mathrm{~h}$, cells were washed and incubated for $20 \mathrm{~min}$ in $4 \mathrm{ml}$ methionine-free Eagle's minimal essential medium (EMEM; GIBCO BRL) containing HEPES, pH 7.2. After the addition of $100 \mu \mathrm{Ci}\left[{ }^{35} \mathrm{~S}\right] \mathrm{methionine/}$ cysteine Trans label (L-methionine, $\left[{ }^{35} \mathrm{~S}\right]$, L-cysteine, $\left[{ }^{35} \mathrm{~S}\right], 1,000 \mathrm{Ci} /$ $\mathrm{mmol}$ ), the transfected cells were incubated at $37^{\circ} \mathrm{C}$ in $5 \% \mathrm{CO}_{2}$. At regular time intervals, the cells were placed on ice. Medium was aspirated immediately, cells were washed once with PBS and harvested in RIPA buffer (1\% Triton X-100, 1\% deoxycholate, 0.1\% SDS, $0.15 \mathrm{M}$ $\mathrm{NaCl}, 5 \mathrm{mM}$ EDTA, $50 \mathrm{mM}$ Tris, $\mathrm{pH}$ 7.4). After passage through a pasteur pipette to shear the DNA, the samples were centrifuged for $20 \mathrm{~min}$ at $4^{\circ} \mathrm{C}$. Cell extracts were immunoprecipitated as previously described with the antibody AR 52 and analyzed on 9\% acrylamide gels containing SDS (6). Samples were transferred to Immobilon ${ }^{\mathrm{TM}}-\mathrm{P}$ (Millipore Corp., Bedford, MA), the filters exposed to $\mathrm{x}$-ray film and the AR bands quantitated by laser densitometric absorbance scanning using a LKB Ultra scanner (Pharmacia Fine Chemicals, Piscataway, NJ) and analyzed using Gelscan $\mathrm{XL}^{\circledR}$ version 2.1 (Pharmacia).

For determination of AR degradation rates, the protocol described for determining efficiency of translation was modified such that the COS cells were incubated with medium containing the ${ }^{35} \mathrm{~S}$ Trans label for $30 \mathrm{~min}$, washed with PBS and incubated for 2, 4, or $6 \mathrm{~h}$ in medium containing $1 \mathrm{nM}$ DHT. Cells were harvested in RIPA after the specified time intervals of incubation and processed as described (6).

Northern blot analysis. Total RNA was extracted from transfected COS cells by the acid guanidinium thiocyanate phenol method 
(17) using TRIzol ${ }^{\mathrm{TM}}$ (GIBCO BRL) and stored at $-80^{\circ} \mathrm{C}$. Northern blot analysis of AR mRNA was performed as described (18) with minor modifications. $10 \mu \mathrm{g}$ of total RNA was denatured with glyoxal and dimethylsulfoxide and fractionated in $1 \%$ agarose gels containing $10 \mathrm{mM} \mathrm{NaPO}$, $\mathrm{pH}$ 6.8. A 335-bp hAR DNA fragment extending from nucleotide 2559 to 2894 of the cDNA sequence (4) was synthesized by PCR and labeled to $\geq 10^{7} \mathrm{cpm} / \mu \mathrm{g}$ DNA specific activity with [ $\left.{ }^{32} \mathrm{P}\right] \mathrm{dCTP}(3,000 \mathrm{Ci} / \mathrm{mmol}$; Amersham, Arlington Heights, IL) by random priming using Random Primed DNA labeling kit (Boehringer Mannheim, Mannheim, Germany) according to manufacturer's instructions. Hybridization reactions were carried out overnight in $0.75 \mathrm{M} \mathrm{NaCl}, 7.5 \mathrm{mM}$ sodium citrate, $\mathrm{pH} 7.0,5 \mathrm{X}$ Denhardts, $0.1 \%$ SDS, $100 \mu \mathrm{g} / \mathrm{ml}$ sheared salmon sperm DNA at $68^{\circ} \mathrm{C}$. Filters were washed to high stringency using $1.5 \mathrm{mM} \mathrm{NaCl}, 1.5 \mathrm{mM}$ sodium citrate, $\mathrm{pH} 7.0,0.1 \%$ SDS at $50^{\circ} \mathrm{C}$ for $1 \mathrm{~h}$. Filters were exposed to Kodak $\mathrm{X}$-OMAT ${ }^{\mathrm{TM}} \mathrm{AR} \mathrm{x}$-ray film at $-80^{\circ} \mathrm{C}$ with intensifying screens. After AR analysis, Northern blots were stripped by boiling in $0.5 \%$ SDS for 5 min and hybridized with a $18 \mathrm{~S}$ ribosomal RNA cDNA probe, $\mathrm{pTZ}$ RNA $18 \mathrm{~S}^{\mathrm{TM}}$ (Ambion, Inc., Austin, TX) to standardize for RNA loaded in each sample. Autoradiograms were analyzed by laser densitometry as described above.

\section{Results}

AR gene sequence. To determine the molecular basis of partial AIS in this family, the coding region of the AR gene was amplified from genomic DNA of subject II-1 by PCR. Agarose gel electrophoresis of PCR products indicated that all eight exons were present. Screening by DGGE of exons 2-8 indicated the absence of a base change in these exons. The region encoding the amino-terminal domain within exon A was analyzed by direct sequencing. A guanine $(\mathrm{G})$ to adenine $(\mathrm{A})$ base mutation was identified at the fourth nucleotide $3^{\prime}$ of the A nucleotide of the ATG initiation codon. This mutation converted the second codon from GAA to AAA and resulted in a glutamic acid (E) to lysine $(\mathrm{K})$ substitution at the extreme amino terminus of AR (Fig. 2). Identical results were obtained in subjects II-4 and II-10. The CAG glutamine repeat within exon A numbered 21 residues in all 3 subjects. The polymor-

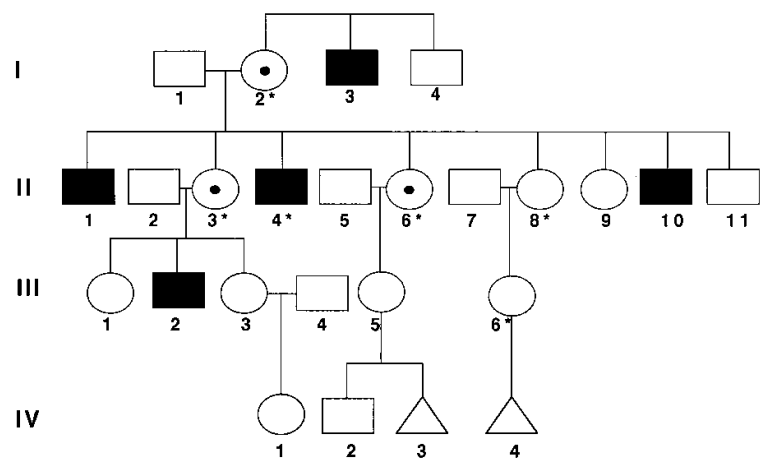

Figure 1. Family pedigree demonstrates X-linked inheritance of ambiguous genitalia consistent with the partial androgen insensitivity syndrome. (ם) Affected; $(\odot)$ carrier; $(\square / \bigcirc)$ unaffected; $(\triangle)$ fetus of unknown sex. Subjects: I-3, II-1, II-4, II-10, and III-2 were 46 XY males born with ambiguous genitalia. Female sex of rearing was initially assigned to I-3, II-1, and III-2. This was reversed to male in middle childhood for I-3 and II-1. Subject III-2, reared as female, had a gonadectomy at $14 \mathrm{yr}$ of age. Asterisk denotes female family members screened for the EK2 mutation. The absence of the EK2 mutation was confirmed by direct sequencing in III-6.
A

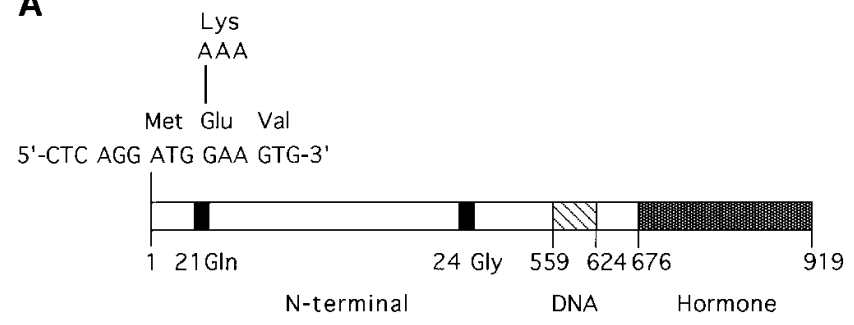

B

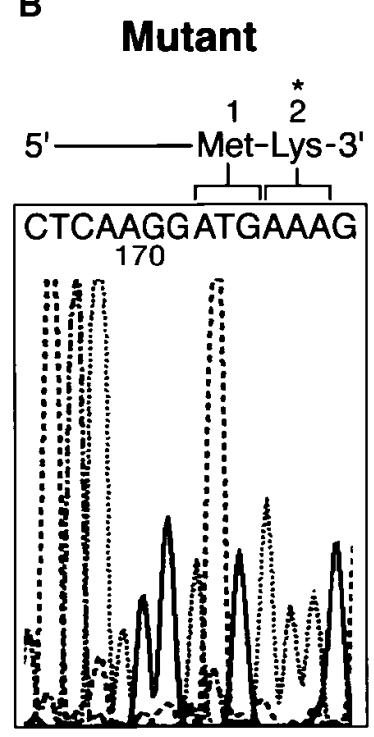

Wild type

C

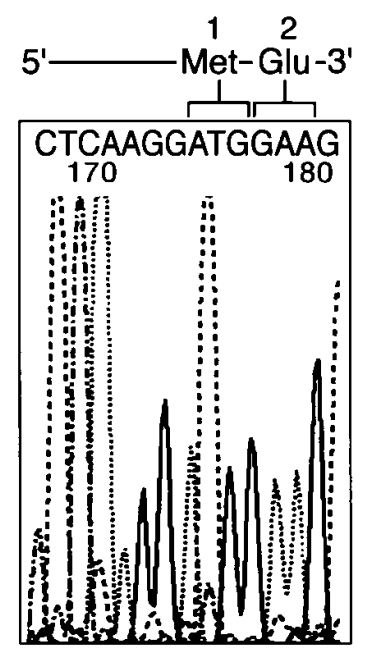

C $+1+4$

Optimal 5' - GCC ACC ATG G - 3'

Wild type 5' - TCA AGG ATG G - 3'

\section{Mutant EK2 5' - TCA AGG ATG A - 3'}

Figure 2. (A) Schematic representation of the single base mutation identified in exon 1 of the AR gene of three affected individuals with partial AIS. The $\mathrm{G} \rightarrow \mathrm{A}$ transition mutation at nucleotide position +4 resulted in a glutamic acid to lysine substitution at amino acid residue 2 (EK2) adjacent to the initiation methionine residue (shown above). The 21 Gln and 24 Gly repeat segments in these patients are depicted. The exons coding DNA and hormone binding domains (indicated) had normal nucleotide sequence. The amino acid codon numbers are indicated below. $(B)$ Black and white reproduction of a color tracing of the nucleotide sequence analysis of the portion of the AR gene of affected subject $\mathrm{XY}$ II-1 showing the $\mathrm{G} \rightarrow \mathrm{A}$ mutation at position +4 . A tracing of the wild type sequence AR gene is shown on the right. The four nucleotides are represented by broken and dashed lines. The nucleotides and their amino acid codons are indicated above their respective peaks. Asterisk indicates the alteration of $\mathrm{G}$ at +4 to $\mathrm{A}$ in the EK2 mutant sequence. $(C)$ Consensus optimal sequence for protein translation initiation (2) where the A of the ATG codon is designated +1 compared to the wild type AR and EK2 mutant AR sequences are shown. 
phic glycine repeat numbered 24 in II- 1 . The absence of a mutation in exons 2-8 suggested by DGGE, was confirmed by direct sequencing. Three heterozygote carriers of the mutant EK2 allele (subjects I-2, II-3, and II-6) were identified by a PCR based strategy using a mutagenic primer (Fig. 3), subjects II-8 and III- 6 who were potential carriers of the AR gene mutation had only the normal allele.

Androgen binding of the mutant AR transiently expressed in COS cells. To investigate the effect of the glutamic acid to lysine substitution on AR function, the mutation was constructed in an expression plasmid containing the human AR cDNA using PCR directed mutagenesis. Mutant and wild type AR cDNAs were transiently expressed in COS cells and androgen binding properties of expressed wild type and mutant AR were examined using $\left[{ }^{3} \mathrm{H}\right] \mathrm{R} 1881$. Scatchard analysis of high affinity $\left[{ }^{3} \mathrm{H}\right] \mathrm{R} 1881$ binding demonstrated similar equilibrium dissociation constants $\left(K_{\mathrm{d}}\right)$ for the mutant EK2 $\left(K_{\mathrm{d}}=\right.$
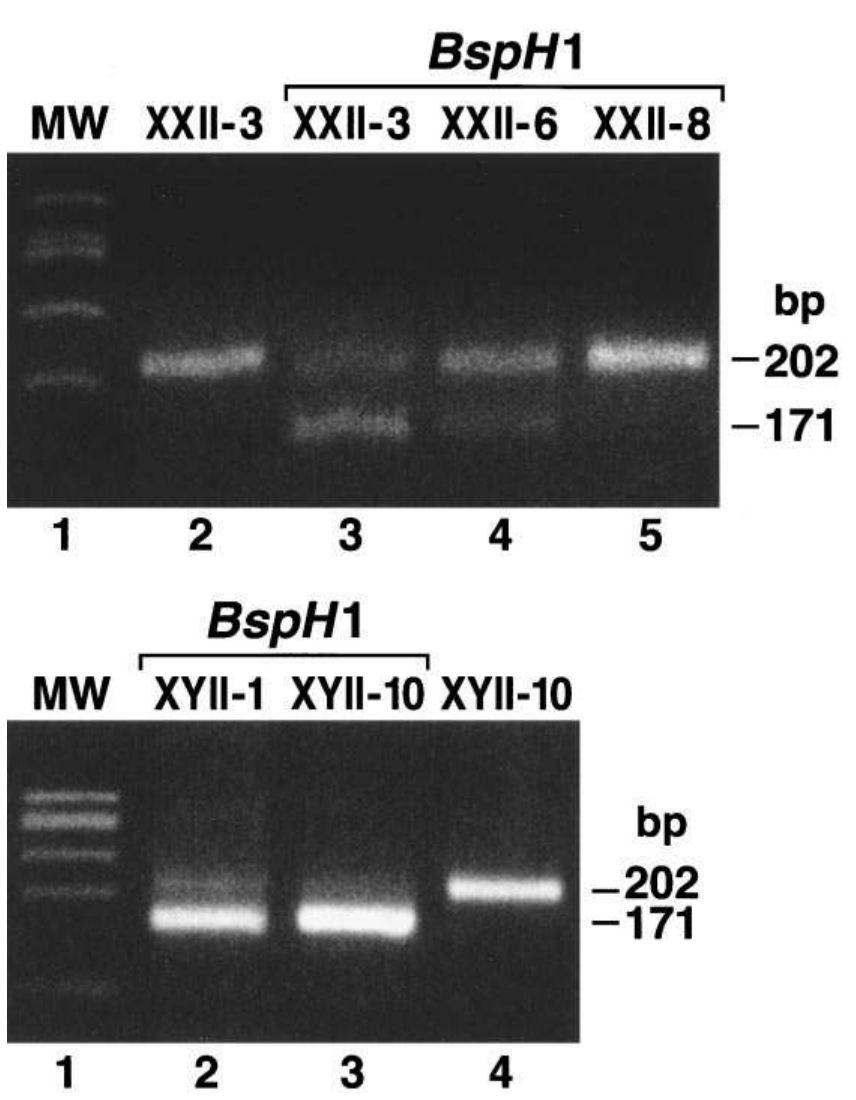

Figure 3. Detection of the EK2 mutation in the AR gene of heterozygote carriers in ethidium bromide stained $2 \%$ agarose gels containing PCR products. PCR amplification of a fragment encompassing the EK2 mutation was accomplished using a mutagenic primer. A BspHI site was created by the EK2 mutation, resulting in a single 171-bp fragment in affected $46 \mathrm{XY}$ individuals on restriction enzyme digestion, a single undigested 202-bp fragment in unaffected males and two bands in XX heterozygote carriers. (Top) Molecular weight markers (lane 1), undigested PCR product from subject XX II-3 (lane 2); after BspHI digestion: normal (202-bp) and mutant (171-bp) alleles are apparent in genomic amplifications from subjects XX II-3 and XX II-6 (lanes 3 and 4); only the normal (202-bp) allele in XX II-8 (lane 5). (Bottom) Molecular weight markers (lane 1); PCR products from two affected 46 XY males, XY II-1 and XY II-10 after digestion (lanes 2 and 3); lane 4 shows undigested PCR product from subject XY II-10.
$0.70 \pm 0.14(\mathrm{SE}) \mathrm{nM}, \mathrm{Bmax}=0.52 \pm 0.17 \mathrm{pmol} / \mathrm{mg}$ protein, $n=$ $6)$ and wild type $\operatorname{AR}\left(K_{\mathrm{d}}=0.64 \pm 0.11 \mathrm{nM}, \mathrm{Bmax}=0.96 \pm 0.43\right.$ $\mathrm{pmol} / \mathrm{mg}$ protein, $n=6$, Fig. 4$)$. The $\left[{ }^{3} \mathrm{H}\right] \mathrm{R} 1881$ dissociation rates for transiently expressed $\mathrm{EK} 2$ mutant $\mathrm{AR}\left(t_{1 / 2}=\right.$ $1.7 \pm 0.08$ (SE) h, $n=5$ ) were slightly increased compared with wild type $\operatorname{AR}\left(t_{1 / 2}=2.4 \pm 0.11 \mathrm{~h}, n=5\right)(P<0.001)$ (Fig. 5).

Transcriptional activity of EK2 AR. Transcriptional activity of EK2 mutant AR was assessed in CV1 cells cotransfected with the reporter plasmid MMTV-luciferase. At the lower concentration of $10 \mathrm{ng}$ transfected plasmid, EK2 induced 50\% less transcriptional activity in absolute optical units than wild type receptor assayed in parallel under identical conditions (Fig. 6A). Induction of luciferase activity by EK2 was equal to or greater
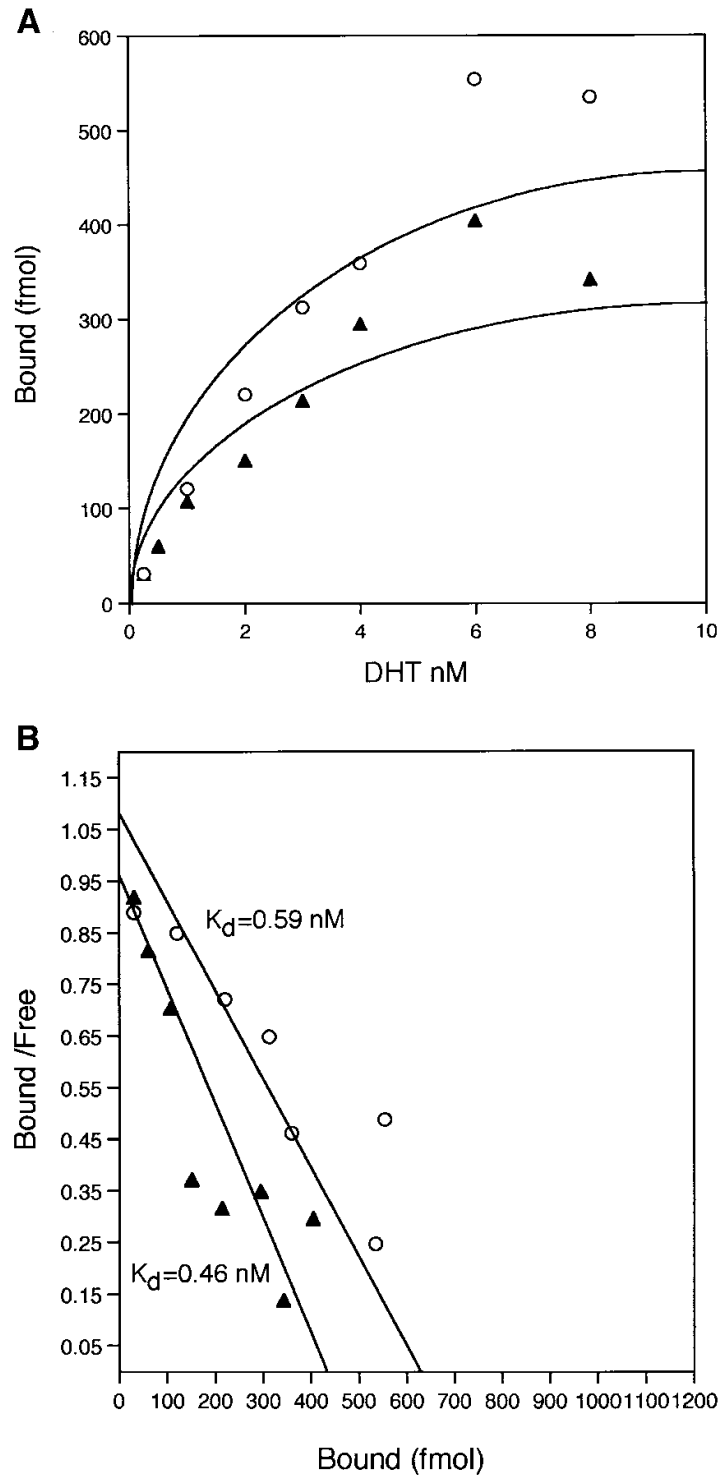

Figure 4. Androgen binding of the mutant AR EK2 recreated in vitro. Saturation plot $(A)$ and Scatchard analysis $(B)$ from a representative experiment of $\left[{ }^{3} \mathrm{H}\right] \mathrm{R} 1881$ binding performed in duplicate in COS cells transfected with wild type $(O)$ or EK2 $(\Delta)$ AR cDNA expression vectors. Equilibrium dissociation constants $\left(K_{\mathrm{d}}\right)$ were similar for the mutant EK2 $\left(K_{\mathrm{d}}=0.70 \pm 0.14[\mathrm{SE}] \mathrm{nM}, \mathrm{Bmax}=0.52 \pm 0.17\right.$ $\mathrm{pmol} / \mathrm{mg}$ protein, $n=6)$ and wild type AR $\left(K_{\mathrm{d}}=0.64 \pm 0.11 \mathrm{nM}\right.$, $\mathrm{Bmax}=0.96 \pm 0.43 \mathrm{pmol} / \mathrm{mg}$ protein, $n=6$ ). 


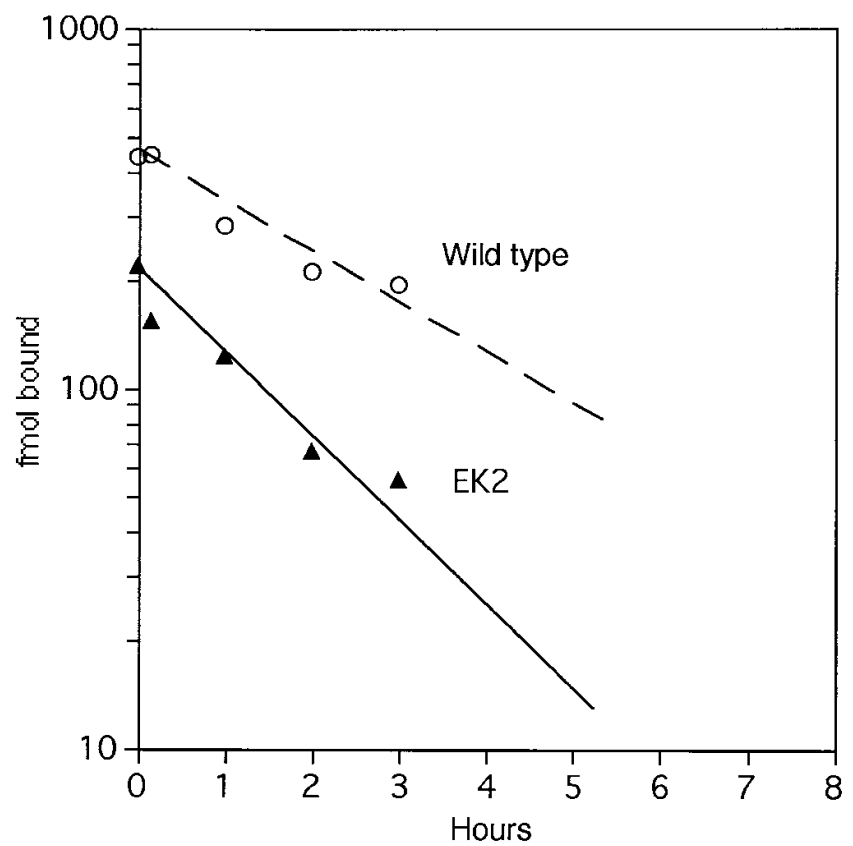

Figure 5. Kinetics of androgen dissociation from wild type and mutant EK2 AR. Wild type $(\bigcirc)$ and EK2 $(\mathbf{\Lambda})$ expression vectors were transiently expressed in COS cells and incubated with $5 \mathrm{nM}$

$\left[{ }^{3} \mathrm{H}\right] \mathrm{R} 1881$. After a $2 \mathrm{~h}$ labeling period, dissociation was initiated by changing the media to contain a 10,000 fold excess of unlabeled $\mathrm{R} 1881$. Specific binding activity was determined as the difference in counts determined in the presence and absence of a 100-fold excess R1881 added at the beginning of the labeling period. The half time $\left(t_{1 / 2}\right)$ represents the time required for dissociation of half of the bound counts. A single representative dissociation curve of five experiments performed using transfected wild type and mutant AR is shown. For pCMVhAR, $t_{1 / 2}=2.4 \pm 0.11[\mathrm{SE}] \mathrm{h}$; for EK2, $t_{1 / 2}=1.7 \pm 0.08 \mathrm{~h}, n=5$ $(P<0.001)$.

than that of wild type AR only when $100 \mathrm{ng}$ of expression vector was transfected and incubated with greater than $0.1 \mathrm{nM}$ DHT (Fig. $6 A$ ). However, fold induction of luciferase activity, which represents the ratio of activity observed in cells treated with steroid versus that in untreated cells transfected with the same vector, was similar for EK2 and wild type at both concentrations of transfected DNA (Fig. $6 B$ ).

Expression of the mutant $A R$. To test the hypothesis that the efficiency of protein translation is reduced by the EK $2 \mathrm{mu}-$ tation, AR protein in COS cells $48 \mathrm{~h}$ after transfection was determined by immunoblot analysis using the AR 52 anti-peptide antibody. The level of expression of EK2 AR protein was $50 \%$ lower than that of the wild type AR at 0.2 and $0.6 \mu \mathrm{g}$ of transfected expression vector. At the higher concentrations of 1 and $4 \mu \mathrm{g}$ of transfected cDNA, EK2 levels were $\sim 38$ and $20 \%$, respectively, lower than wild type AR. Reduced EK 2 expression relative to wild type AR was observed in four separate experiments when $0.2-1 \mu \mathrm{g}$ of cDNA and in three out of four experiments when $4 \mu \mathrm{g}$ of cDNA expression vector was transfected (Fig. 7).

To ascertain whether the lower level of mutant AR protein expression resulted from differences in AR mRNA, Northern analysis for AR mRNA (Fig. 8, $A$ and $B$ ) was carried out using COS cells transfected with $0.2-4 \mu \mathrm{g}$ of expression plasmid DNA cultured in parallel conditions as described above for
AR protein expression. No significant difference was observed between EK2 mutant and wild type AR mRNA levels indicating that the reduced level of EK2 AR protein observed in COS cells is not attributable to decreased mRNA expression or stability.

To investigate further the mechanism underlying reduced expression of the mutant AR protein, the relative translation efficiencies of EK2 and wild type AR mRNA were compared by quantitation of $\left[{ }^{35} \mathrm{~S}\right]$ methionine Trans-labeled AR protein expressed in COS cells immediately after pulse labeling. At the 5 and 10 min time points, the amount of EK2 AR protein expressed was $\sim 50 \%$ less than that of wild type AR $(P=0.01$, $n=5)$. At later time points up to $60 \mathrm{~min}$ after labeling, no significant differences between mutant and wild type AR protein expression were observed $(P>0.4)$ (Fig. 9).

In the absence of DHT the degradation rate of EK2 protein was not statistically different from that of wild type AR $\left(\mathrm{EK} 2 t_{1 / 2}=1.4 \pm 0.1[\mathrm{SE}] \mathrm{h}\right.$, wild type: $t_{1 / 2}=1.8 \pm 0.1 \mathrm{~h}, n=3$ ) $(P=0.06)$. The rate of degradation of the EK2 and wild type AR protein also did not differ in the presence of $1 \mathrm{nM}$ DHT $\left(\mathrm{EK} 2: t_{1 / 2}=2.7 \pm 0.5[\mathrm{SE}] \mathrm{h}\right.$, wild type: $t_{1 / 2}=2.9 \pm 0.5 \mathrm{~h}, n=3$ ).

\section{Discussion}

We have identified a novel missense mutation in the second codon of the amino-terminal domain of the $A R$ gene in three related subjects with grade III partial AIS. The $\mathrm{G} \rightarrow$ A substitution at nucleotide position +4 of the coding sequence resulted in an amino acid change from glutamic acid to lysine and altered the nucleotide context of the initiator codon. A survey of the 5' ends of 699 vertebrate mRNA sequences has previously demonstrated a conserved pattern of nucleotides surrounding the functional initiator codon (19). The optimal context derived from this survey was $5^{\prime}-\mathrm{CC}_{\mathrm{G}}^{\mathrm{A}} \mathrm{CCA} \mathbf{+ 1} \mathbf{U} \mathbf{H G}^{+4}-3^{\prime}$ (19). Within that sequence, the purine in position -3 on the $5^{\prime}$ side of the AUG is the most highly conserved, while $3^{\prime}$ of the AUG codon, $\mathrm{G}$ is the preferred flanking nucleotide, occurring in $46 \%$ of all mRNAs examined. In only 23 out of 699 was there a pyrimidine at the -3 position and 17 of these contained a $G$ at the +4 position (19). Systematic mutagenesis of nucleotides adjacent to the ATG initiator codon in preproinsulin expression confirmed the dominant effect of the purine in position -3 with a hierarchy of $\mathrm{A}>\mathrm{G}>\mathrm{T}$ in modulating the yield of protein (20). Alteration of $\mathrm{G} \rightarrow \mathrm{T}$ in the +4 position immediately $3^{\prime}$ to the initiation codon was associated with a $50 \%$ reduction in efficiency of translation; however, the effect of a $\mathrm{G} \rightarrow \mathrm{A}$ substitution in +4 was not determined (20). Nucleotide alterations in positions $-1,-2,-4$, and -5 had no measurable effect when the preproinsulin mutant contained the optimal A in position -3 and $G$ in position +4 (20). The wild type human AR mRNA sequence $5^{\prime}$-CA $\underline{A}$ GGAUGG-3' contains $A$ in the -3 position and $\mathrm{G}$ in position +4 but differs from the consensus sequence at positions $-1,-2,-4$, and -5 (2).

We assessed the effect of the $\mathrm{G} \rightarrow \mathrm{A}$ EK2 mutation at position +4 on AR protein expression using quantitative immunoblot analysis. The level of mutant AR protein expression was reduced by $\sim 20-50 \%$ compared with that of wild type AR (Fig. 7) while mRNA levels were similar in COS cells transfected with either EK2 or wild type AR (Fig. 8), thus the reduced level of EK2 AR protein observed in COS cells is not attributable to decreased mRNA expression or stability. 


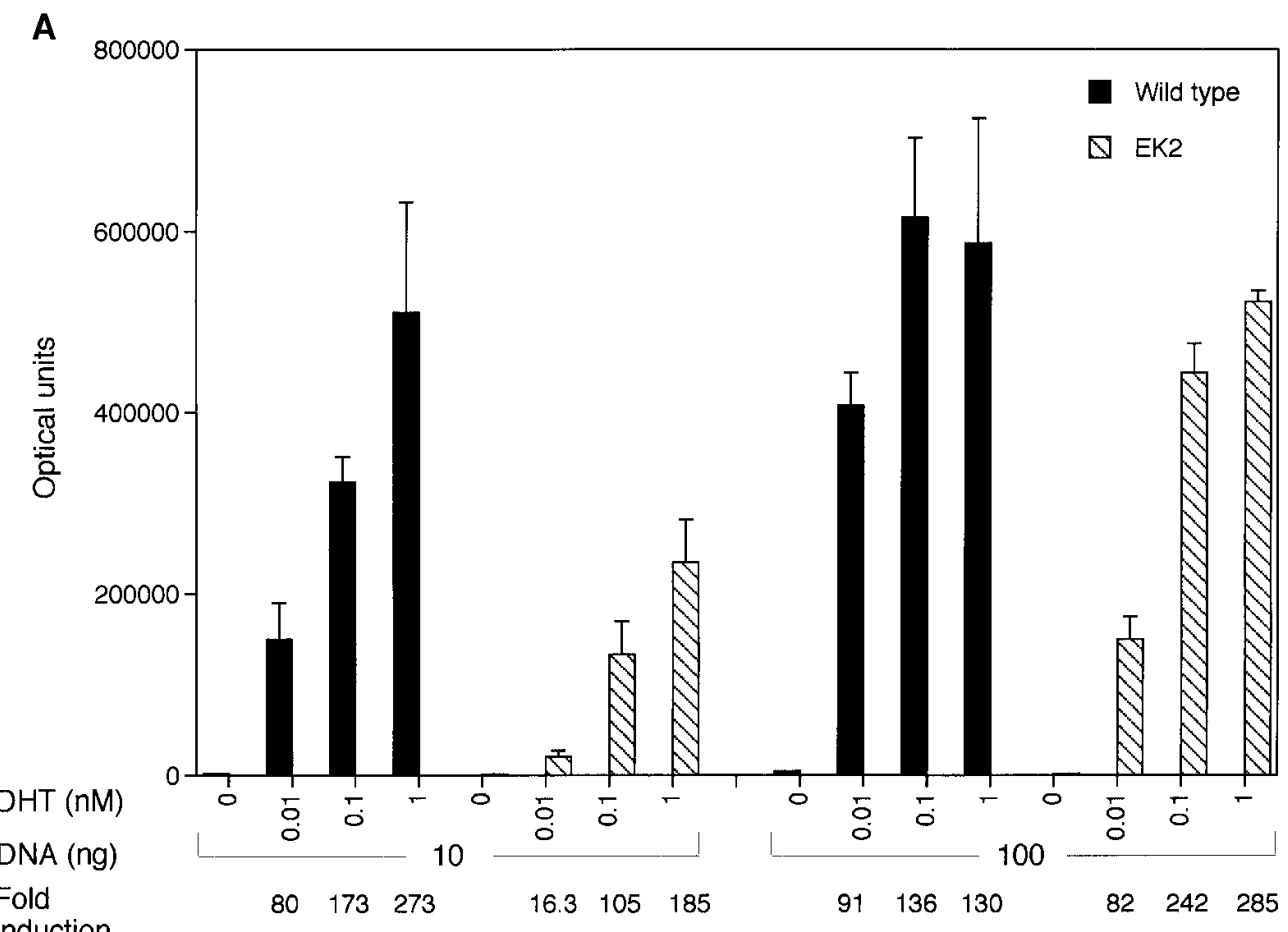

induction
B

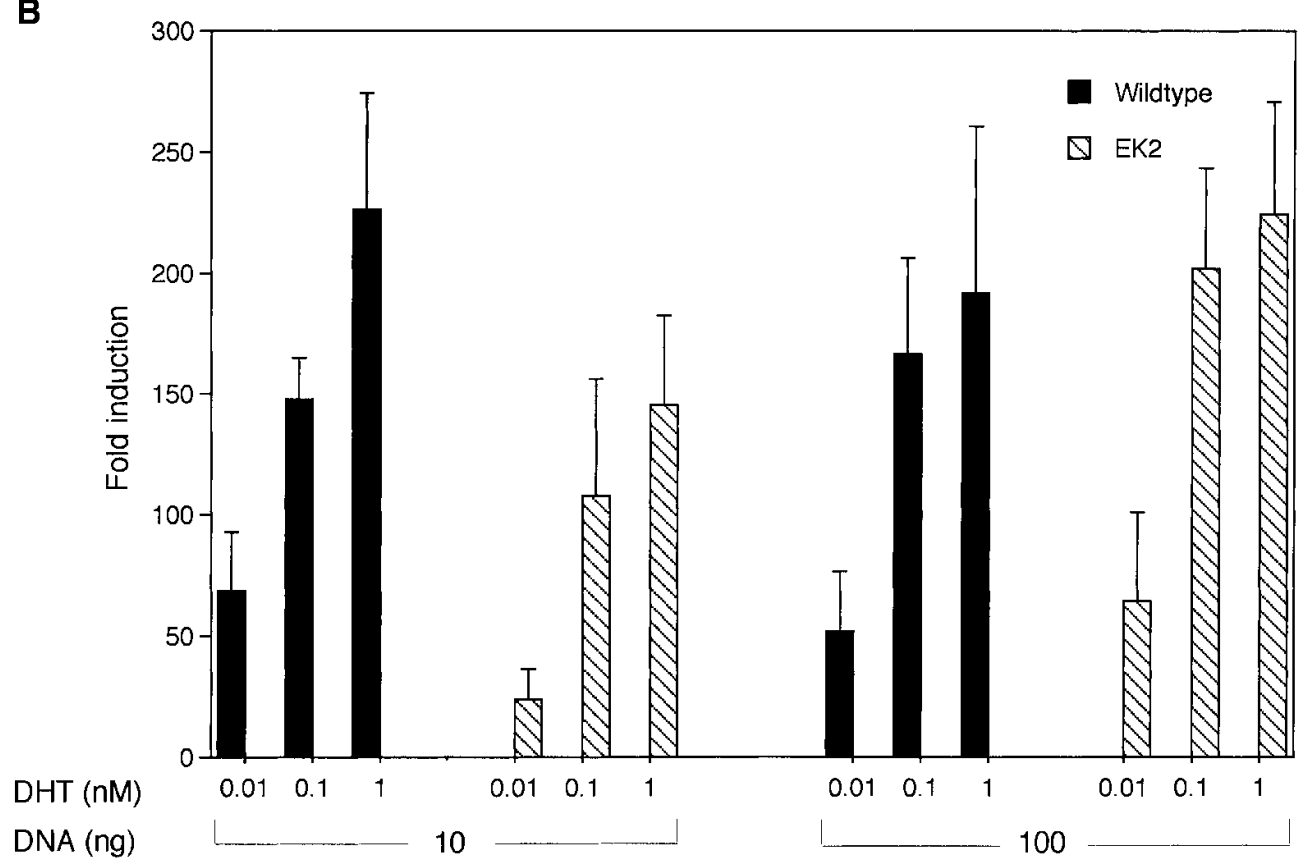

Figure 6. Transcriptional activation of an androgen responsive reporter gene by wild type and EK2 AR. (A) CV1 cells were transiently transfected with plasmids encoding either wild type or EK2 AR with expression vector DNA at 10 or $100 \mathrm{ng}$ and the reporter plasmid MMTV-luciferase $(5 \mu \mathrm{g})$. After transfection, cells were incubated with increasing concentrations of DHT for $48 \mathrm{~h}$, harvested, and assayed for luciferase activity. The figure displays a representative experiment showing a dose dependent increase in transcriptional activity of both the wild type and EK2 mutant AR induced by DHT in absolute light units. Bars represent the mean of triplicates \pm SE. (B) Transcriptional activity is plotted as fold induction which represents the ratio of luciferase activity in DHT treated cells to that in untreated cells transfected with the respective vector. The average from five independent experiments is shown.
In translation experiments, the $\mathrm{G} \rightarrow \mathrm{A}$ substitution at +4 identified in the $h A R$ from this AIS family reduces translation of EK2 mutant AR protein. The amount of radiolabeled mutant AR protein synthesized within the first 10 min was $50 \%$ lower than that of wild type AR. This negative effect of the EK2 mutation on translation likely results in lower steady state mutant AR protein levels in vivo and leads to a severe partial AIS phenotype. A precedent for such a mechanism is provided by the report of a subject with $\alpha$ thalassemia (Haemoglobin $\mathrm{H}$, $\beta$-chain tetramers) in whom a deletion of the two nucleotides preceding the ATG initiation codon which altered the se- quence of the $\alpha$ globin gene from $5^{\prime}$-ACCATG-3' to $5^{\prime}$-CCCATG-3' was associated with defective production of $\alpha$-globin protein (21), even though levels of $\alpha$ globin mRNA in reticulocytes were the same as in two unaffected subjects. The authors of this study concluded that the defective output of $\alpha$ chains most likely resulted from decreased efficiency of $\alpha$ globin mRNA translation. Our findings of equivalent AR mRNA levels in COS cells transiently expressing wild type or EK2 mutant AR are consistent with the above observations that alteration of the optimal nucleotide context for translation initiation can result in reduced protein synthesis. In unpublished 
A

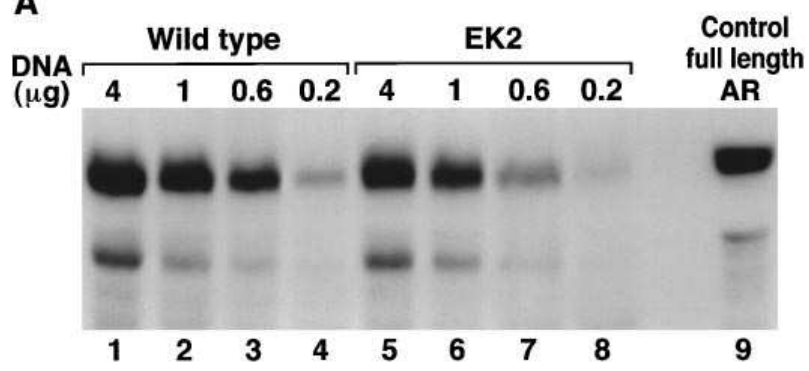

B

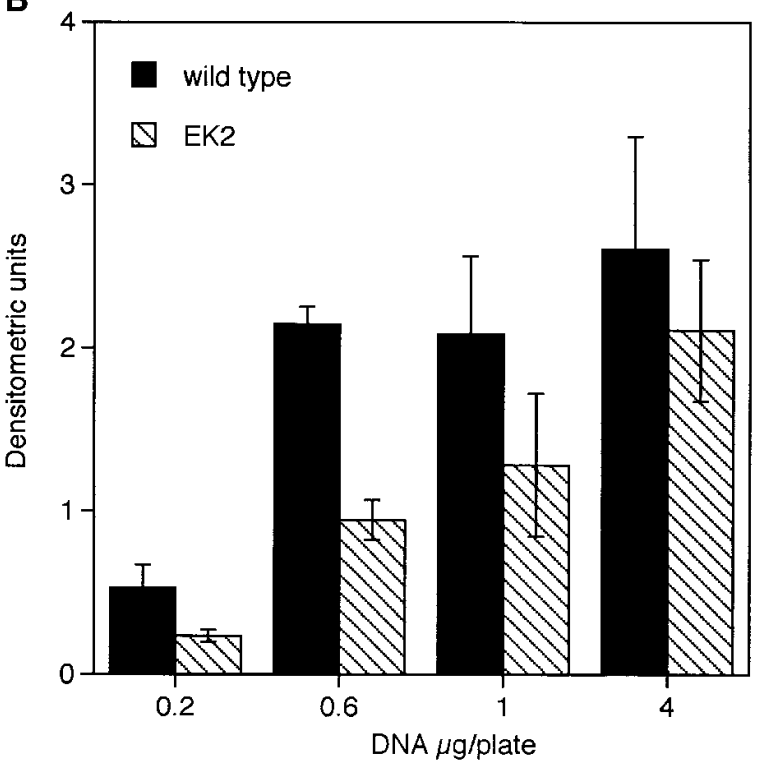

Figure 7. Immunoblot quantitation of AR protein. COS cells were transfected in duplicate with increasing amounts of AR mutant or wild type expression vector cDNA, incubated in Dulbecco's modified medium, $\mathrm{pH} 7.2$, supplemented with $10 \%$ fetal calf serum, $20 \mathrm{mM}$ Hepes, $\mathrm{pH} 7.2$, and antibiotics in humidified $5 \% \mathrm{CO}_{2}$ and harvested at $48 \mathrm{~h}$. Immunoblot analysis was performed using the rabbit anti AR polyclonal antibody AR 52 and a fluorescein tagged goat anti-rabbit IgG antibody. ( $A)$ A representative blot of COS cell extracts after transfection with 4-0.2 $\mu \mathrm{g}$ per plate of wild type AR cDNA vector (lanes 1-4) and with EK2 cDNA (lanes 5-8). Lane 9 contains full length AR derived from baculovirus infected Sf9 cells (33). The upper band is the full length AR protein. Each lane represents an equal volume of extract obtained from a plate of 400,000 cells. (B) Densitometric analysis of three immunoblots prepared as described above. The bars represent the mean $\pm \mathrm{SE}$ of $\mathrm{AR}$ protein levels expressed in densitometric units at each concentration of AR DNA transfected and indicates that transient EK2 expression (hatched bars) deviates from wild type (solid bars) by $50 \%$ at lower concentrations and 38 and $20 \%$ at the higher concentrations of 1 and $4 \mu \mathrm{g}$, respectively.

studies, we have observed in another family the phenotype of partial AIS associated with reduced expression of a functionally normal AR supporting the requirement for AR expression at a critical threshold level.

In keeping with the normal ligand binding domain sequence of the EK2 mutant, the equilibrium affinity binding constant for $\left[{ }^{3} \mathrm{H}\right] \mathrm{R} 1881$ was normal. However, normal kinetics of androgen binding require an interaction between the AR amino terminus and the ligand binding domain. The increased dissociation rate of bound $\left[{ }^{3} \mathrm{H}\right] \mathrm{R} 1881$ from the EK2 mutant is con-
A

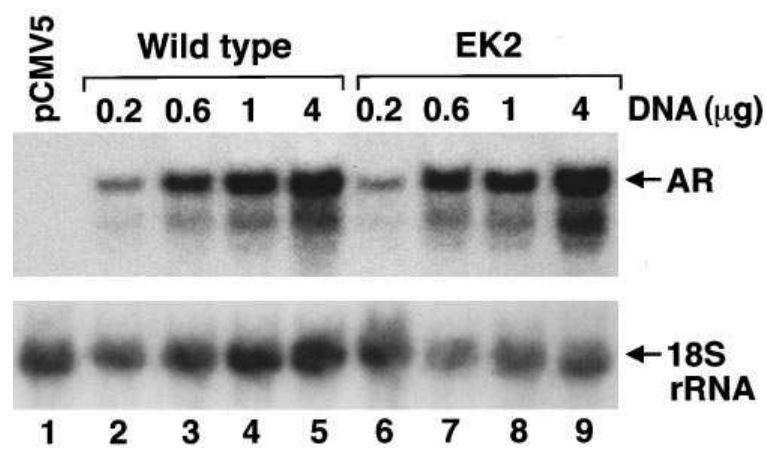

B

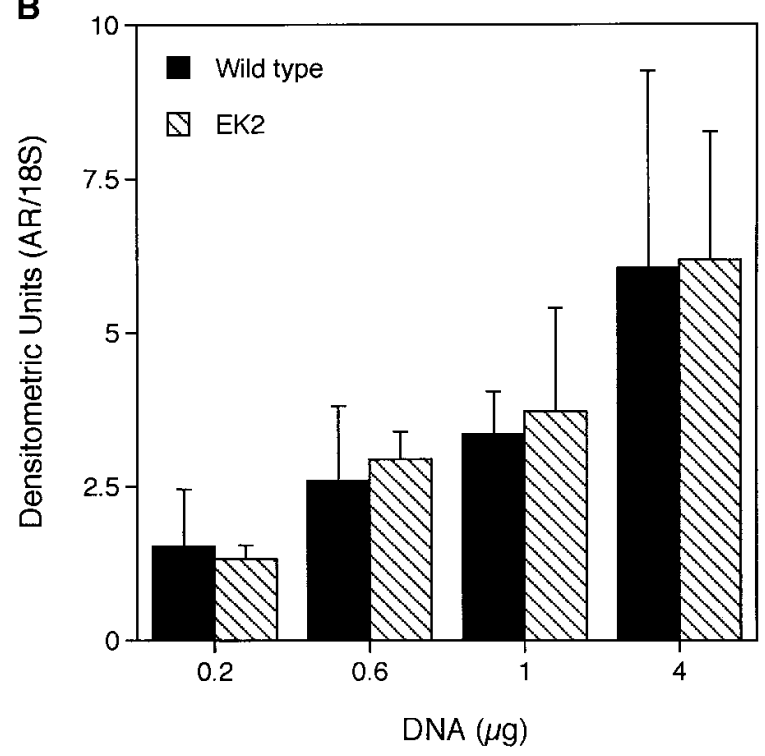

Figure 8. Northern blot of AR mRNA in transfected COS cells. AR mRNA was isolated from $4.5 \times 10^{5} \mathrm{COS}$ cells $48 \mathrm{~h}$ after calcium phosphate transfection of indicated amounts of DNA performed as described for immunoblot analysis of AR. Aliquots of total RNA (10 $\mu \mathrm{g})$ were analyzed by blot hybridization using an AR DNA probe as described in Methods. $(A)$ A representative blot is shown of RNA extracted from COS cells after transfection with $4 \mu \mathrm{g}$ per plate of control parent vector pCMV5 (34) (lane 1), 0.2-4 $\mu \mathrm{g}$ wild type AR cDNA (lanes 2-5) and mutant EK2 AR cDNA vector (lanes 6-9). (Top) Hybridization with AR cDNA probe. (Bottom) The blot was stripped and hybridized with $18 \mathrm{~S}$ rRNA cDNA probe to control for RNA loading. $(B)$ The radioactive bands on autoradiographs were quantified by laser densitometry for AR and $18 \mathrm{~S}$ rRNA. The data points representing the mean of four transfections \pm SE of AR RNA expressed in transfected COS cells and standardized against $18 \mathrm{~S}$ RNA are plotted in densitometric units versus the amount of DNA transfected per plate.

sistent with but less marked than that observed in AR aminoterminal deletion mutants (6). The naturally occurring ligand binding domain mutation VM889 (22) which resulted in tenfold increased rate of ligand dissociation, was also associated with enhanced AR degradation (6). The small apparent increase in the degradation rate of EK2 noted in the absence of DHT did not reach significance $(P=0.06)$. Accordingly the rate of receptor degradation was similar for EK2 and wild type AR in the presence of DHT. However small increases in dissociation of bound androgen and AR degradation resulting from al- 
teration of the normal amino and carboxy-terminal interaction within the mutant EK2 AR could exacerbate reduced AR protein levels and thereby contribute to the phenotype of partial AIS.

The reduced AR transactivation of the MMTV-luciferase reporter gene by the EK2 mutant compared with wild type $\mathrm{AR}$, at $10 \mathrm{ng}$ of transfected expression vector is consistent with the reduction of EK2 AR protein expression at the lower level of transfected DNA. When $100 \mathrm{ng}$ of transfected cDNA was used in the presence of $\geq 0.1 \mathrm{nM}$ DHT, transcriptional capacity of the EK2 mutant approached wild type levels. Thus the higher concentration of steroid compensated for the effect of
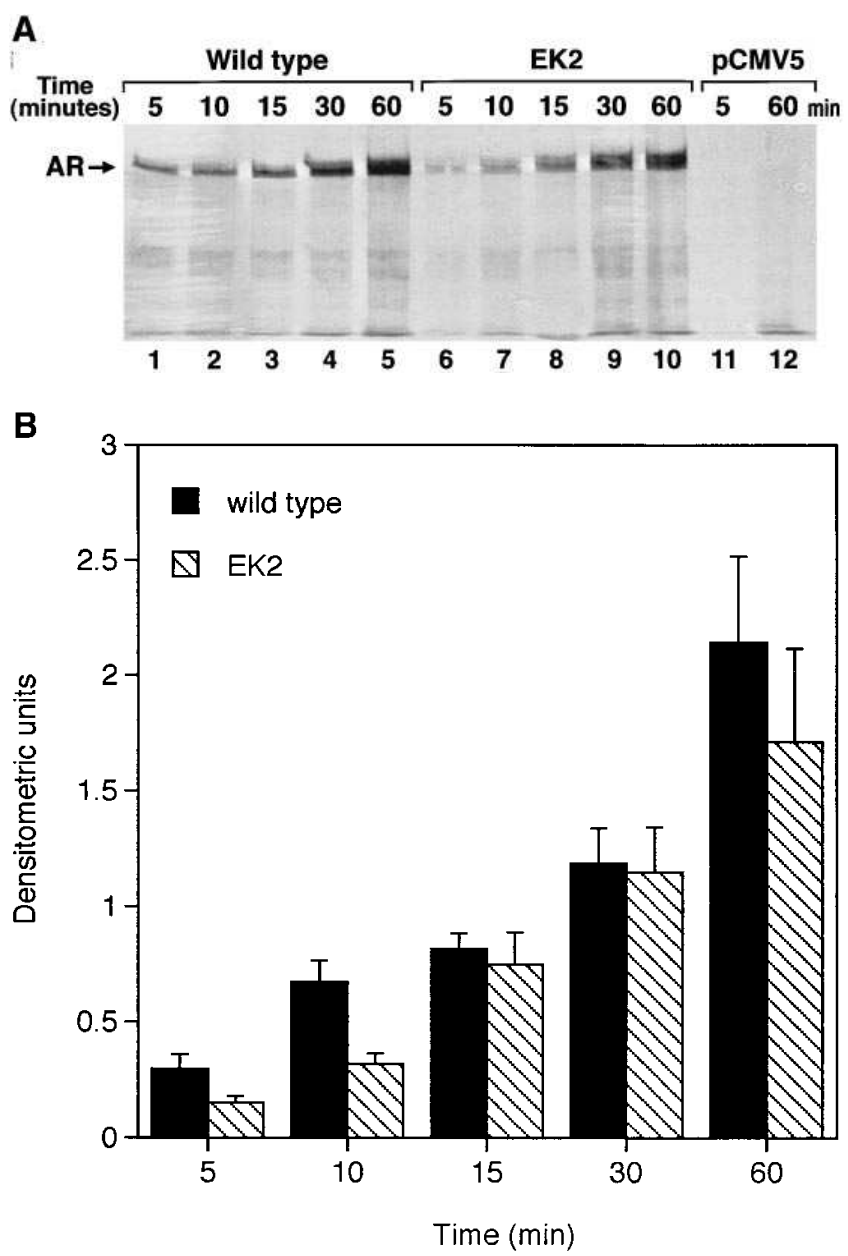

Figure 9. Differences in wild type and EK2 AR synthesis in COS cells. ${ }^{35} \mathrm{~S}$ ] $m$ ethionine Trans-labeled AR expressed in COS cells transfected with $10 \mu \mathrm{g} / 1.2 \times 10^{6}$ cells of wild type or EK2 expression vector cDNA using DEAE dextran. Cells were harvested at specified intervals immediately after pulse labeling. Radiolabeled AR was immunoprecipitated using AR 52 antibody and fractionated on an SDS polyacrylamide gel, the proteins were transferred to Immobilon $^{\mathrm{TM}}-\mathrm{P}$, and the radioactive bands were quantitated by densitometric scanning. $(A)$ An exposure of a transferred gel of samples from a representative translation experiment is shown. Lanes $1-5$ contain wild type AR; lanes 6-10, EK2 AR; lanes 11 and 12 were loaded with immunoprecipitates from COS cells transfected with the parent vector pCMV5 (34). Above are indicated the times in minutes after addition of $\left.{ }^{35} \mathrm{~S}\right]$ methionine Trans label. (B) Average densitometric scanning results of five experiments presented as a bar graph (hatched bars, EK2 mutant; solid bars, wild type AR) represent the mean \pm SE of protein level expressed in densitometric units for each time point. the EK2 mutation at higher levels of protein expression. However the fold induction achieved with steroid treatment was similar for EK2 and wild type AR at 10 and 100 ng suggesting that the inherent transcriptional capacity of the receptor was similar to wild type AR. The predominant effect of the EK2 mutation is therefore to decrease protein translation.

Intermolecular interactions with the human AR dimer have previously been investigated using a protein interaction assay in which the amino terminus and the carboxyl terminus were fused to the Saccharomyces cervisiae GAL4 DNA binding domain and the herpes simplex virus VP-16 transactivation domain in order to produce chimeric proteins (23). Amino-terminal deletion chimeras in this assay demonstrated that the region near the amino-terminal end contributes to receptor dimerization following high affinity ligand binding. However, this effect was not as strong as that for the amino-terminal region adjacent to the DNA binding domain (23). The single amino acid alteration at position two does not appear to have a substantial effect on receptor dimerization, as indicated by our findings of normal transcriptional activity of the EK2 mutant at higher levels of receptor expression.

With few exceptions, mutations in the human $A R$ gene associated with AIS have been limited to the DNA and steroid binding domains $(9,24-27)$. Types of amino-terminal domain mutations include premature stop codons (28), frameshifts (29, 30) and a single missense mutation, (31) and expansions of the homopolymeric CAG trinucleotide repeat (32). In the present report, we characterize a novel molecular mechanism for AIS resulting from a $\mathrm{G}$ to $\mathrm{A}$ substitution in codon 2 adjacent to the translation initiation codon in the amino-terminal domain of the $A R$ in three related individuals with partial AIS. This is the first report of a naturally occurring mutation that alters the nucleotide context of the ATG initiation codon at the critical G +4 residue, resulting in reduced translation efficiency.

\section{Acknowledgments}

We are grateful to Drs. F. MacDonald and C. McKeown (West Midlands Regional Clinical Genetics Service, Clinical Genetics Unit, Birmingham Maternity Hospital, Edgbaston, Birmingham, United Kingdom) for referring the patients to us and for providing clinical information, to Jiann-an Tan for technical advice and J.A. Kemppainen, D.-Y. Zhang, K. Hamil, and M. Cobb for technical assistance.

This work was supported by grants HD16910, HD04466, and P30 HD18968 from the National Institute of Child Health and Human Development Center for Population Research and a Research Award 95-193 from the Genentech foundation for Growth and Development. C.S. Choong is a recipient of a 1994 Fellowship from the Channel 7 Telethon Trustees of Western Australia.

\section{References}

1. Marschke, K.B., J.-A. Tan, S.R. Kupfer, E.M. Wilson, and F.S. French. 1995. Specificity of simple hormone response elements in androgen regulated genes. Endocrine. 3:819-825.

2. Lubahn, D.B., D.R. Joseph, P.M. Sullivan, H.F. Willard, F.S. French, and E.M. Wilson. 1988. Cloning of the human androgen receptor complementary DNA and localization to the X chromosome. Science (Wash. DC). 240:327-330.

3. Chang, C., J. Kokontis, and S. Liao. 1988. Molecular cloning of human and rat complementary DNA encoding androgen receptors. Science (Wash. DC). 240:324-326.

4. Lubahn, D.B., D.R. Joseph, M. Sar, J.-A. Tan, H.N. Higgs, R.E. Larson, F.S. French, and E.M. Wilson. 1988. The human androgen receptor: complementary deoxyribonucleic acid cloning, sequence analysis and gene expression in the prostate. Mol. Endocrinol. 2:1265-1275.

5. Tilley, W.D., M. Marcelli, J.D. Wilson, and M.J. McPhaul. 1989. Charac- 
terization and expression of a cDNA encoding the human androgen receptor. Proc. Natl. Acad. Sci. USA. 86:327-331.

6. Zhou, Z.-X., M.V. Lane, J.A. Kemppainen, F.S. French, and E.M. Wilson. 1995. Specificity of ligand-dependent androgen receptor stabilization: receptor domain interactions influence ligand dissociation and receptor stability. Mol. Endocrinol. 9:208-218.

7. Simental, J.A., M. Sar, M.V. Lane, F.S. French, and E.M. Wilson. 1991. Transcriptional activation and nuclear targeting signals of the human androgen receptor. J. Biol. Chem. 266:510-518.

8. Zhou, Z.-X., C.-I. Wong, M. Sar, and E.M. Wilson. 1994. The androgen receptor: an overview. Recent Prog. Horm. Res. 49:249-274.

9. Quigley, C.A., A. De Bellis, K.B. Marschke, M.K. El-Awady, E.M. Wilson, and F.S. French. 1995. Androgen receptor defects: Historical, clinical, and molecular perspectives. Endocr. Rev. 16:271-321.

10. Kozak, M. 1991. Structural features in eukaryotic mRNAs that modulate the initiation of translation. J. Biol. Chem. 266:19867-19870.

11. John, S.W.M., G. Weitzner, R. Rozen, and C.R. Scriver. 1991. A rapid procedure for extracting genomic DNA from leukocytes. Nucleic Acids Res. 19:48.

12. De Bellis, A., C.A. Quigley, N.F. Cariello, M.K. El-Awady, M. Sar, M.V. Lane, E.M. Wilson, and F.S. French. 1992. Single base mutations in the androgen receptor gene causing complete androgen insensitivity: rapid detection by a modified denaturing gradient gel electrophoresis technique. Mol. Endocrinol. 6:1909-1920.

13. Choong, C.S., M.J. Sturm, J.A. Strophair, R.K. McCulloch, W.D. Tilley, P.J. Leedman, and D.M. Hurley. 1995. Partial androgen insensitivity caused by an androgen receptor mutation at amino-acid 907 (Gly Arg) that results in decreased ligand binding affinity and reduced androgen receptor messenger ribonucleic acid levels. J. Clin. Endocrinol. Metab. 81:236-243.

14. Kelce, W.R., C.R. Stone, S.C. Laws, L.E. Gray, J.A. Kemppainen, and E.M. Wilson. 1995. Persistent DDT metabolite p,p'-DDE is a potent androgen receptor antagonist. Nature (Lond.). 375:581-585.

15. Tan, J.-A., D.R. Joseph, V.E. Quarmby, D.B. Lubahn, M. Sar, F.S. French, and E.M. Wilson. 1988. The rat androgen receptor: primary structure, autoregulation of its messenger RNA and immunocytochemical localization of the receptor protein. Mol. Endocrinol. 2:1265-1275.

16. Lowry, O.H., N.J. Rosebrough, A.L. Farr, and R.J. Randal. 1951. Protein measurement with the Folin phenol reagent. J. Biol. Chem. 193:265-268.

17. Chomcynski, P., and N. Sacchi. 1987. Single step method of RNA isolation by acid guanidinium thiocynate-phenol-chloroform extraction. Anal. Biochem. 162:156-159.

18. Quarmby, V.E., W.G. Yarbrough, D.B. Lubahn, F.S. French, and E.M. Wilson. 1990. Autologous down regulation of androgen receptor messenger ribonucleic acid. Mol. Endocrinol. 4:22-28.

19. Kozak, M. 1987. An analysis of 5'-noncoding sequences from 699 vertebrate messenger RNAs. Nucleic Acids Res. 15:8125-8148.

20. Kozak, M. 1986. Point mutations defined a sequence flanking the AUG initiator codon that modulates translation by eukaryotic ribosomes. Cell. 44 : 283-292.

21. Morlé, F., B. Lopez, T. Henni, and J. Godet. 1985. Thalassaemia associ- ated with the deletion of two nucleotides at position -2 and -3 preceding the AUG codon. EMBO. (Eur. Mol. Biol. Organ.) J. 4:1245-1250.

22. De Bellis, A., C.A. Quigley, K.B. Marschke, M.K. El-Awady, M.V. Lane, E.P. Smith, M. Sar, E.M. Wilson, and F.S. French. 1994. Characterization of mutant androgen receptors causing partial androgen insensitivity syndrome. J. Clin. Endocrinol. Metab. 78:513-522.

23. Langley, E., Z.-X. Zhou, and E.M. Wilson. 1995. Evidence for an antiparallel orientation of the ligand-activated human androgen receptor dimer. $J$. Biol. Chem. 270:29983-29990.

24. McPhaul, M.J., M. Marcelli, S. Zoppi, J.E. Griffin, and J.D. Wilson. Genetic basis of endocrine disease 4 . The spectrum of mutations in the androgen receptor gene that causes androgen resistance. J. Clin. Endocrinol. Metab. 76 : $17-23$

25. Brown, T.R. Human androgen insensitivity syndrome. 1995. J. Androl. 16:299-303.

26. Pinsky, L., M. Trifiro, M. Kaufman, L.K. Beitel, A. Mhatre, P. KazemiEsfarjani, M. Sebbaghian, S. Lumbroso, C. Alvardo, M. Vasilou, and B. Gottleib. 1992. Androgen resistance due to mutations of the androgen receptor. Clin. Invest. Med. 15:456-472.

27. Brinkmann, A.O., G. Jenster, C. Ris-Stalpers, J.A. van der Korput, H.T. Bruggenwirth, A.L. Boehmer, and J. Trapman. 1995. Androgen receptor mutations: review. J. Ster. Biochem. Mol. Biol. 53:443-448.

28. Zoppi, S., C.M. Wilson, M.D. Harbison, J.E. Griffin, J.D. Wilson, M.J. McPhaul, and M. Marcelli. 1993. Complete testicular feminization caused by an amino-terminal truncation of the androgen receptor with downstream initiation. J. Clin. Invest. 91:1105-1112.

29. Batch, J.A., D.M. Williams, H.R. Davies, B.D. Brown, B.A.J. Evans, I.A. Hughes, and M.N. Patterson. 1992 Androgen receptor gene mutations identified by SSCP in fourteen subjects with androgen insensitivity syndrome. Hum. Mol. Genet. 1:497-503.

30. Hiort, O., A. Wodtke, D. Struve, A. Zollner, and G.H. Sinnecker. 1994 Detection of point mutations in the receptor gene using non-isotopic single strand conformation polymorphism analysis. German Collaborative Intersex Study Group. Hum. Mol. Genet. 3:1163-1166.

31. Vasilou, M., M. Trifiro, and L. Pinsky. 1994. Mutations of the N-terminal domain of the human androgen receptor associated with androgen resistance syndrome. Program of the $76^{\text {th }}$ Annual Meeting of the Endocrine Society. Anaheim, CA. (Abstr. 1179). p. 454

32. La Spada, A.R., E.M. Wilson, D.B. Lubahn, A.E. Harding, and K.H Fischbeck. 1991. Androgen receptor mutations in X-linked spinal and muscular atrophy. Nature (Lond.). 352:77-79.

33. Wong, C.I., Z.-X. Zhou, M. Sar, and E.M. Wilson. 1993. Steroid requirement for androgen receptor dimerization and DNA binding: modulation by intramolecular interactions between the $\mathrm{NH}_{2}$-terminal and steroid binding domains. J. Biol. Chem. 268:19004-19012.

34. Andersson, S., D.N. Davis, H. Dählback, H.D. Jörnval, and D.W. Russell. 1989. Cloning, structure and expression of mitochondrial cytochrome P-450 sterol 26-hydroxylase, a bile acid biosynthetic enzyme. J. Biol. Chem. 264:82228229. 